\title{
«ЖИИВПИСНЫЙ ПОРТРЕТ» В ЛИТЕРАТУРНОМ ТЕКСТЕ: РОМАНТИЧЕСКИЙ И МОДЕРНИСТСКИЙ ДИСКУРС
}

\section{В.А. Герасимчук}

Фаустинская тема продажи души дьяволу, в аксиологическом аспекте звучащая как тема обмена духовных ценностей на материальные, актуализируется всегда, в любом тексте философской прозы, поскольку она касается духовных основ бытия, субстанции, лежащей в антропософской плоскости - сохранению человеческого в человеке. Существует множество поэтико-структурных способов ее художественного воплощения, ее художественной интерпретации. Два писателя (Н. Гоголь и О. Уайльд), принадлежащие к двум разным духовным культурам и двум разным стилевым направлениям - романтизму и модернизму, в качестве инструментария исследования фаустианской темы избрали принцип вербальной перекодировки живописного портрета, который, наряду с другими образами, начал жить собственной жизнью, став сквозной смысловой доминантой, проявляющейся на протяжении всего текстового пространства. Нам представляется, что сопоставление на основе дифференциации и параллелизма двух «живописных» субстанций, с одной стороны, позволит проследить особенности их эстетического функционирования в литературном тексте, проанализировать их перцепцию, духовные и психологические метаморфозы персонажей как следствие взаимодействия их с «портретом»; с другой - поможет выявить структурно-содержательные элементы из арсенала романтической (Гоголь) и модернистской (Уайльд) поэтики. В последнем случае, в частности, вырисовывается и особенно интересный срез проблемы: использование Уайльдом в модернистской эстетике переосмысленных романтических приемов. Здесь, в плане творческой переклички между писателями, можно говорить лишь об опосредованном присутствии в тексте Уайльда элементов гоголевской поэтики. Посредни-

Актуальні проблеми духовності

(Відп. ред.: Я.В. Шрамко)

Кривий Ріг (2005), 217-228 
ком можно считать Достоевского, которого Уайльд хорошо знал и любил и который, в свою очередь, считал себя преемником Гоголя (вспомним его признание: «Все мы вышли из „Шинели“»). О непосредственном же влиянии на Уайльда творчества Гоголя, его «Портрета» ни в плане генезиса, ни в плане типологии вопрос пока еще никем не ставился.

Общим мотивом двух текстов является мотив разрушения личностного начала, нравственной и умственной деградации человека под влиянием искушающей демонической силы. И в первом и во втором случае речь идет о героях, приближенных к искусству, любящих и понимающих его, тем не менее, эстетическое чувство не играет особенной роли в их судьбах. Гоголевский герой - художник Чартков (в первой редакции повести Чертков), талантливый и перспективный, вынужден был влачить бедное существование. На последние деньги он покупает странный портрет ростовщика, который и «помогает» ему разомкнуть круг бедности. Посыпавшиеся на Чарткова «золотые червонцы» «портретного» ростовщика (что равноценно продажи души дъяволу), решительным образом меняют и его жизнь, и его мировоззрение, и его эстетические принципы: он становится «модным художником», заказчики от него требуют только одного, чтоб было «хорошо и скоро». Угождая их вкусу, Чартков, меняет весь свой творческий процесс, «который вел к совершенству», на элементы холодного «академического» икусства, выполненные с «нервной поспешностью» («Художник увидел, что оканчивать решительно было невозможно, что все нужно было заменить ловкостью и быстрой бойкостъю кисти. Схватыватъ одно только целое, одно общее выраженъе и не углубляться кистью в утонченные подробности» [2, т. 3, с. 88]). И все бы ничего, да однажды он пришел на выставку картин своего бывшего товарища по академии, «который от ранних лет носил в себе страсть к искусству; с пламенною силою труженика погряз в нем всею душою своею и для него, оторвавшись от друзей, от милых привычек, бросился без всяких пособий в неизвестную землю; терпел бедность, унижение, даже голод, но с редким самоотвержением, презревши все, был бесчувствен ко всему, кроме своего милого искусства» [2, т. 3, с. 234-235]. Чартков стоял перед его полотнами «с отверстым pтом» $[2$, т. 3, с. 235], поняв, наконец, что, распылив свой талант, как художник он не состоялся («в тридцать с лишним лет труднее изучать скучную лестничу трудных правил и анатомии, еще труднее постигнуть то вдруг, что развивается медленно и дается за долгие усилия, за великие напряжения, за глубокое самоотвержение» [2, т. 3, с. 237]). Чартков попытался начать рисовать как прежде, но уже не смог. За соблазн иметь все и сразу, он жестоко расплатился - «неосуществлением» себя как истинно творческого человека, что равнозначно «неосуществлению» жизни. Черная зависть, затмившая разом все его чувства, подвигла 
художника на страшное преступление, он стал покупать на вернисажах шедевры, которые с безумным сладострастием уничтожал. Вся темная, демоническая сила, проснувшаяся в Чарткове, отразилась и во всем его внешнем облике, приблизив его многими чертами к «портрету ростовщика» («эта ужасная страсть набросила какой-то страшный колорит на него: вечная желчь присутствовала на лище его. Хула на мир и отрицание изображалосъ само собой в чертах его. Кроме ядовитого слова и вечного порицанья, ничего не произносили его уста. Подобно какой-то гарпии, попадался он на улице, и все его знакомые, завидя его издали, старались увернуться и избегнуть такой встречи, говоря, что она достаточна отравить потом весъ денъ» [2, т. 3, с.96]). Художник сходит с ума и умирает, а портрет ростовщика на глазах изумленной публики странным образом исчезает с выставки.

Герой Уайльда, художник Бэзил Холлуорд, создал портретный шедевр молодого, красивого юноши Дориана, в который вложил всю свою душу, и подарил этот портрет его прототипу. Их общий приятель Гарри искушает Дориана, предлагая ему «поменяться местами» с портретом; «жить и стариться» вместо него будет портрет, а он останется навсегда молодым и красивым. Дориан под «неусыпным» влиянием умного и циничного Гарри (модернистский вариант Мефистофеля Гете) очень быстро пускается во все тяжкие. Портрет становится все безобразнее и безобразнее. А Дориана все сильнее затягивает бездна порока. В конце концов, он в приступе ярости убивает художника, потом себя, превращаясь в омерзительного старика, а на портрете опять появляется изображение прекрасного юноши.

Как мы видим, «живописный портрет» в обоих текстах выполняет и концептуально-смысловую и сюжетно-композиционную функцию. «Портретное» присутствие жестко детерминирует фабульное действие (завязку, кульминацию, развязку), сюжетную событийность (преимущественно в психологическом наполнении). Композиционно «Портрет» Гоголя исполнен в двухмерной перспективе («всевидящее око» «омерзительного старика» неустанно следит за художником и ведет его лабиринтами «красивой, богатой, но такой поверхностной жизни»), а «Портрет Дориана Грея»-в трехмерной (Гарри-искуситель-герой-портрет). Гарри, ни на шаг не отступая от героя в течение всей его жизни, провоцирует, целенаправленно подталкивает к нравственной пропасти, вытравливает из его души остатки совести, что зеркально отражается в «портретных» чертах героя. Но при всем типологическом сходстве и близости художественных ролей искусителей, отведенных им в тексте, образ «портретного» ростовщика и образ аристократа Гарри разнятся по их эстетико-фукциональной сущности. Образ ростовщика рассмотрен Гоголем в традиционных дихотомических оппозициях: материальное-духовное, демоническое- 
божественное, безнравственное-нравственное. Гоголь-романтик не принимал и опровергал действительность (о чем свидетельствуют его письма) которая, по его мнению, имела вид «скучной физиономии банкира, наслаждающегося своими миллионами», а в Петербурге, утверждал писатель, «кроме фонаря все дышит обманом» [2, т. 7, с.69]. Гоголь всегда шел от фольклорных мотивов, которыми пронизаны его ранние повести, от народного представления о том, что богатство всегда пахнет кровью (в одной из его повестей есть такой императив: чтобы овладеть золотом, нужно убить невинного ребенка). Образ ростовщика, торговца всегда был чужд Гоголю, в нем он видел угрозу духовности («рыночная толпа не должна знать к ней (могиле поэта-В.Г.) дороги, с ней довольно славного имени nоэта» [2, т. 7, с. 203]. Его «портретный ростовщик»-это символ губительной власти денег, которые осуществляют эту власть повсечасно и повсеместно, искушая и покупая человека, запугивая и обманывая, льстя ему и терзая завистью.

Герой романа Уайльда Гарри, аристократ и эстет, на первый взгляд, играет такую же неприглядную роль искусителя в жизни своего подопечного Дориана Грея, как и «портретный ростовщик» в жизни Чарткова. Но более точная интерпретация этого персонажа возможна в понятиях парадоксальной логики, которую Уайльд часто использует как художественный прием. Уже портретные черты лорда Гарри («смуглое романтическое лицо») вступают в противоречие с общественным мнением о нем как о цинике и имморалисте. При более близком знакомстве с героем высвечивается основное противоречивое свойство его характера, несоответствие провозглашенных им теоретических суждений жизненной практике. Провоцируя Дориана Грея на неприглядные поступки, на эпикурейство, а вскоре и на преступные действия, сам-то он ничего подобного не совершает. «Удивителъный ты человек! Никогда не говоришь ничего нравственного - и никогда не делаешь ничего безнравственного» [7, с.11] - это слова художника Бэзила, адресованные Гарри. При всех высоких пафосных словах об искусстве, о красоте он живет с обычной женщиной, что очень поразило Дориана, который все, что ни говорит Гарри, воспринимает буквально, как руководство к действию. А Гарри ведет с ним очень тонкую циничную интеллектуальную игру, игру в понятия и слова, рассуждения «без берегов» (вид своеобразного эстетства) - смысл и цель которой можно объяснить многими понятиями ницшеанской философии жизни (воля, власть, надчеловек). Гарри можно считать также и учеником «бесов» Достоевского. Модернизм как игра с формами, предвидит и ситуацию, когда жизнь героя моделируется либо автором, либо от его лица другими героями произведения. Жизнь Дориана и есть модель поведения, которая запрограммирована интеллектом Гарри. Но в то же время, как нам представляется, автор всю вину за свое нравственное 
падение перекладывает на Дориана, который в обществе размытых ценностей должен сам делать выбор и отвечать за него. Гарри намекал ему на выбор: «стать зрителем собственной жизни - это значит уберечь oт земных страданий» [7, с.87]. Но Дориан не понял, что «страдание и есть главная истина жизни» (Гарри), и не откорректировал свою жизнь.

Оба автора не обходят и проблемы социальных условий, в которых вынуждены делать выбор герои. На рыночной стадии развития общества, когда ценность выступает средством обмена, вездесущность денег играет растленную роль, ведь капитал наделен способностью маскироваться и часто незаметно (но безжалостно) осуществляет свою власть. Это особенно ощущают на себе представители творческих профессий, положение которых зачастую низводится до уровня услуг. Заказчица дама, чувствуя свое превосходство перед художником, говорила с ним так, как «обыкновенно. . . говорят с художниками, франиузскими парикмахерами и прочими людъми, рожденными для удовольствия других» [2, т. 3, с.86]. Талантливый художник в «Портрете» Уайльда тоже не на первых ролях в своем обществе («...нам бедным художникам, следует время от времени появляться в обществе, хотя бы для того, чтобы показать людям, что мы не дикари» [7, с.12]. Оба «омерзительных старика» на портретах - это и есть воплощение «рыночной» реальности, поверхностного «материального» бытия героев, их неумение жить духовными категориями, благородными чувствами и страданиями. В обоих текстах портреты меняются местами с реальностью. Меняющийся портрет Уайльда - это реальность, а реальность Дориана Грея растворяется в образах, реминисценциях, в зеркальных отражениях одного в другом, превращаясь в иллюзию. Он любит только образы. Девушка, которую, как ему казалось, он полюбил, нравилась ему только в образе, в маске, когда она играла, когда же она влюбилась по-настоящему и стала естественной, он к ней остыл. Система зеркальных отражений в тексте, широко представленная в модернистской эстетике, складывалась еще в романтической культуре. «Портрет» Гоголя - это зеркало, которое сфокусировало конечный итог жизни героя. Суета светской жизни и легкие деньги завуалировали глубинный смысл портрета, его знак, который как бы подан сверху художнику, но он его не заметил и не почувствовал. «Портрет Дориана Грея»это тоже зеркало, отражающее реальность, ее качественные изменения, метаморфозы души героя ( $B$ этом зеркале он когда-то впервые по-настоящему увидел свое лицо, а теперь увидит свою душу» [7, с.84].

«Живописные портреты» представляют собой не только отражающую сущность, но и перцептивную, влияющую. Любое изменение в чертах лица изображенного Дориана Грея, вызывает всплеск эмоций прототипа. Важным средством гипнотического воздействия на жертву является взгляд и насмешливая улыбка, которые передаются и жертве, не выдерживаю- 
щей искушения. Уайльд: «. . . лицо на портрете показалосъ ему изменившимся. Выражение было какое-то другое, - в складке рта чувствовалась жестокость. . каждый грех ложился пятном на портрет, портя его красоту...» [7, с. 82]. Когда Дориан Грей после решения измениться и начать новую жизнь, с надеждой решил взглянуть на портрет, «крик возмущения и боли вырвался у него. Никакой перемены! Только в выражении глаз было теперь что-то хитрое, да губы кривила лищемерная усмешка. Человек на портрете был все так же отвратителен, отвратительнее прежнего. . .» [7, с. 167]. Гоголь: «Это был старик с каким-то беспокойным и даже злобным выражением лица; в устах его была улыбка, резкая, язвительная, и вместе какой-то страх; румлнеи, болезни был тонко разлит по личу, исковерканному морщинами; глаза его были велики, черны, тусклы; но вместе с этим в них была заметна какая-то странная живость» [2, т. 3, с. 219]. «Глаза старика» стали преследовать Чарткова, видоизменили его сознание к расщепленному восприятию, доведя в конечном счете до безумия: «Ему начали чудитъся давно забытые, живые глаза необыкновенного портрета, и тогда бешенство его было ужасно. Все люди, окружавшие его постель, казались ему ужасными портретами. Он двоился, четверился в его глазах; все стены казались увешаны портретами, вперившими в него свои неподвижнъе, живые глаза. Страшные портреты глядели с потолка, с полу, комната расширялась и продолжалась бесконечно, чтобы более вместить этих неподвижных глаз» $[2$, т. 3, с.96]. Модернистский и авангардный принцип зеркальных отражений («портрет старика» двоится, четверится , множится, со всех сторон на героя смотрят его глаза), который можно считать художественным открытием Гоголя, широко использовался в литературе 20 в. Истоки этого принципа следует искать в мифологеме ока (см. [1]), трансформированной христианской культурой в мифологемы «всевидящего божественного ока», «всевидящего сатанинского ока». В «портрете» Гоголя «всевидящее сатанинское око» (представленное как оксюморон живое и неподвижное) принадлежит «антихристу», пришедшему на землю «отвоевывать» души людей. Не случайно, художник, нарисовавший портрет ростовщика, спас свою душу только после того, как замолил грехи, и начал рисовать иконы. Спасти свою душу, вернуть себя к достойной жизни, каким-то образом увернуться от «сатанинского влияния» пытались и Чартков и Дориан. Чартков хотел возродить в себе способность к настоящему творчеству, но когда убедился, что это невозможно, пожираемый черным чувством озлобленности, зависти, начал лихорадочно скупать на аукционах живописи шедевры, вставшие перед ним убедительным укором, и варварски их уничтожать. Дориан тоже делал несколько незначительных попыток измениться к лучшему, но это никак не отражалось на портрете, и, не мирясь с таким своим обликом, он уничтожил портрет. 
И Чартков и Дориан таким образом уничтожали только внешние свидетельства своего духовного и душевного распада, внутренняя мотивация их состояния, зафиксированная «живописными портретами», оставалась. Мифологема Достоевского о том, что красота спасет мир, приобретает у Гоголя и Уайльда видоизмененную модификацию, красотой герои пытаются спасти себя, но не могут, потому что к этой красоте примешивается зло. В частности, Чартков хоть и приблизился по многим качествам к портрету ростовщика, он не уничтожает его; по воле автора, он не может этого сделать: портрет ростовщика, это то абсолютное зло, которое уничтожить может только абсолютное добро. Можно сказать, что «живописные портреты» - это главный мыслеобраз двух текстов, в котором заключена одна из самых тревожных тем и Гоголя, и Достоевского, и всей культурософии 20 в. - тема возможной эстетизации зла в искусстве (о решении этой темы Уайльдом в духе «Цветов зла» Бодлера см.: [5]).

Психологическая установка и поведенческая линия каждого героя детерминируется рамками той эстетики, в которой работают писатели: Гоголя привлекают прежде всего романтические принципы и приемы повествования, Уайльда - модернистские. Но их интенсивный поиск новых изобразительных и выразительных форм привел и к тому, что Уайльд часто вступает в диалог с романтической традицией, а в творчестве Гоголя формируются художественные приемы, которые проявились через некоторое время в модернизме.

Оба текста строятся на принципе романтической двуплановости, романтического двоемирия, при этом сходными в них оказываются и соотношения между реальными и ирреальными мирами. С одной стороны, «субъективно-объективный» авторский мир художественной «реальной реальности», в котором превалирует объективное повествование автора, с другой - субъективный, ирреальный мир, отражающий и в первом и во втором случае психологические метаморфозы героев, запечатленные в «живописных портретах». Портрет играет роль зловещей связи между двумя мирами, в которых вынуждены жить герои. Причем борьба рационального и иррационального у Гоголя происходит на уровне разорванного авторского сознания, тогда как два мира О. Уайльда-рационально смоделированный текст. Два мира предоставляют возможность двойной интерпретации, двойной мотивировки событий, как с реалистически-обыденной, так и фантастической трактовки (сон Чарткова и как реальность и как случайные совпадения, цепь иррациональных совпадений характерна и для фабулы Уайльда).

Развитие сюжета в обоих текстах происходит по принципу модальной логики, героям как бы предлагается два варианта жизни, но они выбирают, как им кажется, меньшее зло, чем обрекли себя на романтическую игру с собственной жизнью, игру на смерть, и проиграли. Романтические 
понятия красоты и молодости, романтический вымысел об их вечности стал символом искусства Уайльда, который видел сущность искусства, человека и явлений только в красоте, в молодости, что коррелируется в свою очередь с более поздним постмодернистским дискурсом, утверждающим, что мир принадлежит молодым.

Романтическим жестом может быть и обращение обоих писателей к необычной экзотике (гоголевский азиат-ростовщик, у Уайльда - контрастная низовая культура, атмосфера пабов, герой моряк, брат героини и т.д.); решающие события происходят в темноте, при зашторенных окнах (оживают портреты, осуществляются убийства). Главных героев отличает и некоторая, характерная для романтической эстетики, странность, мрачность. Герой как бы испытывает неодолимое влечение к бурям, штормам, обвалам, ночному мраку. (Расширительную характеристику романтического персонажа см. [4].) Бросается в глаза и крайний индивидуализм героев, чувство превосходства над другими, проявляющееся и в преступных наклонностях, что делает их асоциальными, а то и антисоциальными типами, и выводит за круг любого общества. Причем индивидуализм романтика - это, как правило, не черта характера, а оппозиция по отношению к обществу, которое он не приемлет. Тогда как в модернистской интерпретации, и в частности в творчестве Уайльда, романтический индивидуализм, трансформируясь в эгоизм, становится чертой характера героя (Гарри: «...люди неэгоистичные бесцветны, они утрачивают свою индивидуальность», «своя жизнь - вот самое главное...» [7, с. 32]). Главным психологическим концептом романа Уайльда, который он возводит в теорию, становится производный от эгоизма эстетизированный порок («Наслаждение - это пробный камень, которым она испытывает человека, в знак ее благословения» [7, с.63]). Если у Гоголя порок рассматривается и в традиционной (византийской) религиозной традиции как вечно греховное в человеке, как вечная борьба добра и зла (дъявольское изображение в противоположность просветленному иконописному), и в романтической - без порока нет страстей, именно порок хоть и ведет к деградации личности, подвигает человека к экспрессивному проявлению своих чувств, то Уайльд порок выводит за рамки психологизма. Естественное, природное, религиозное начало - ценности, которыми регламентировалась эстетика романтизма, в модернизме вообще не берутся во внимание, поскольку в романтическом вызове обществу присутствовало нравственное начало, модернисты же делали сознательную попытку развести искусство и общество, признавая только «искусство для искусства». В их представлении и «красивая жизнь» с ее пороками, гедонизмом - это тоже искусство, но, к сожалению, в такой жизни сохранить чистоту души невозможно. Главная идеология «Портрета...» Уайльда идея пан-эстетизма, мораль же переводится в плоскость только межли- 
чностных отношений.

«Портреты» служат также яркой иллюстрацией к пониманию сущности романтической иронии, универсального принципа, сформулированного Ф. Шлегелем. Ирония - скрытая насмешка, а романтическая ирония двойная ирония, которая раскрывает процесс преодоления автором пропасти между идеалом и действительностью. Созданная субъективная реальность вступает в противоречие с объективной реальностью; с одной стороны, автор опровергает жизнь в тех формах, в которых она существует, с другой,- жизнь в лице современного общества опровергает и произведение, и его создателя, и более того, само творение оборачивается против своего творца. K примеру, автор и от его имени герой Гарри манифестировали одни ценности, но художественная логика текста все же подводит к другим выводам: «весь пафос романа заключался в обратном доказательстве: потеря человеком своей нравственной сущности, даже ради искусства и красоты оборачивается для него физической и духовной гибелью» [6, с. 189]. Общество не поняло этого парадокса, восприняло произведение как скрытую насмешку над собой и объявило роман Уайльда аморальным, а самого автора отправили в тюремную камеру. Романтическая ирония «Портрета» Гоголя тоже окрашена пессимистически. Расщепленное сознание автора, воплощенное в расщепленном сознании героя, лихорадочно ищущее свою сущность, в конце концов находит лишь «разорванную действительность» и, потрясенное до безумия, гибнет.

В реальной жизни и Гоголь и Уайльд были близки к миру искусства: вращались в художнической среде, писали статьи об искусстве, Уайльд, к тому же, выступал с блестящими лекциями по эстетике (его отец был знатоком античности). Их глубокие познания в живописи, отразились и в литературной практике, где можно встретить очень много изобразительных и выразительных приемов, заимствованных из этого вида искусства. Живописность - черта стиля обоих писателей. Вербальные пейзажи Гоголя, и природные и урбанистические, живописны по многим признакам, по логике описания - передний план, задний план, по выхваченным из обилия других более значимых объектов, по использованию светотени и т.д. Большинство гоголевских пейзажных зарисовок представляют собой вербальную кодировку живописных пейзажей, в них чувствуется цветовая гармония, определенная тональность, задающая единое настроение целому. Иллюстрацией к его пейзажам могут быть пейзажи М. Куинджи. Живописность Уайльда эстетически другая, исполнена в другой манере - модернистской. Она ищет не естественности, как романтик-Гоголь, а изящества, изысканности, аристократичности. Хотя модернизм использовал и традиционную манеру письма, обращаясь к классическим стилям, в том числе и романтическому. В обоих описаниях «Портрета» мы видим 
игру светом - живописного элемента, при описании комнат, мастерской, портретов. В «портрете» Гоголя («Это был старик с личом бронзового чвета, скулистым, чахлым; черты лица, казалось были схвачены в минуту судорожного движенъя и отзывались несеверною силою. Пламенный полденъ был в них» [2, т. 3, с.66]) и в меняющихся «портретах» Дориана Грея («..в выражении глаз было теперь что-то хитрое, да губы кривила лицемерная усмешка. Человек на портрете был все так же отвратителен, отвратительнее прежнего. . .» [7, с. 166]); («Лицо у него было морщинистое, увядшее, отталкивающее» [7, с. 168]) можно увидеть сходство с портретным мастерством Рембрандта, особенно с его портретами стариков, также несущих печать своей далеко не праведной жизни.

Копия или натура - один из главных вопросов XIX в., волновал и Гоголя, и позже Уайльда. Что мы видим на картине, чью реальность - ответ на эти вопросы искали оба писателя. Эстетический ход мысли Гоголя можно проследить в таких модусных характеристиках. Когда Чартков впервые увидел портрет старика, он нашел в нем что-то «странное» («Это было уже не искусство: это разрушало даже гармонию самого портрета. Это были живые, это были человеческие глаза! Казалосъ, как будто они были вырезаны из живого человека и вставлены сюда. Здесъ не было того уже высокого наслажденъя, которое обгемлет душу при взгляде на произведение художника, как ни ужасен взятый им предмет» [2, т. 3, с.71]). Художник не может слепо копировать натуру, потакать ей, он обречен при этом создавать дисгармонический мир ( Что это? - невольно вопрошал себл художник, - Ведъ это, однако же, натура, это живая натура; отчего же это странно-неприятное чувство? Или рабское, буквальное подражание натуре есть уже проступок и кажется ярким, нестройным криком?» [2, т. 3, с. 71]). Художник не может писать картину с холодным сердцем, не постигая внутренней тайны бытия. Он должен преодолевать в себе негативные, а то и темные инстинкты, чтобы они не проявлялись в его творчестве всепобеждающе. Борьба двух начал божественного (креативного, творческого) и демонического (порочного, греховного) закончилась фиаско для художника Чарткова и для Дориана Грея (автора своего меняющегося изображения), и поэтому их «портреты» содержат «одушевленный порок» - «натуру», преодолеть которую они, как создатели, так и не смогли. Гоголь как бы предоставляет право художнику на изображение всей действительности, но при этом сам писатель не всегда уверенно, но предостерегает от перехода за границу морального, о недопущении зла в искусство. Образцами истинного настоящего искусства в «Портрете» Гоголя являются одна из первых картин Чарткова «Психея» и картина его товарища (прототип - А. Иванов), «не только дивно талантливая», а проникнутая тем «особым чарующим све- 
том, который рождается лишь от чистого огня жертвы и вдохновения» $[1$, с. 73]. В споре, что выше, жизнь или искусство, и Гоголь, и Уайльд отдают предпочтение искусству, оно влияет на жизнь, наделено сверхъестественной силой. Этот вывод дает основание некоторым исследователям творчества Гоголя, рассматривать повесть «как отражение инфернальной эстетики, проникнутой проблематикой трансцендентного в свете ортодоксальной христианской религиозности» $[3$, с. 30$]$, что, на наш взгляд, не совсем правомерно; мы больше склоняемся к мысли, что искусство Гоголь все же рассматривал в духе романтического «европеизма».

И в романтизме, и в модернизме принцип «миметической референциальности» (осознанная соотнесенность художественных произведений с кругом явлений объективной реальности), как мы видим, авторами не соблюдается. Художник Бэзил не хочет отправлять на выставку портрет Дориана, потому что вложил в него свою душу ( $Я$ боюсъ, что nорmрет выдаст тайну моей души» [7, с.12]). Поскольку это портрет души истинного художника, он вечен, тогда как изменяющийся портрет Дориана Грея, портрет его порочной души, обречен на гибель. Творения, в которые переливают все тепло и талант своей души настоящие художники (у Гоголя искупивший свои грехи автор «портрета», пишущий иконы, и талантливый товарищ Чарткова) тоже вечны, тогда как порочный портрет ростовщика таинственно исчезает.

Если Гоголь рассматривает искусство в категориях нравственных, духовных, апеллируя одновременно и к прошлому (чистота средневековой иконописи) и делая прорыв в эсхатологию (у художника есть ученики, которые продолжат его дело), то Уайльд - исключительно в эстетических категориях, используя один из распространенных принципов модернизма - принцип «современного видения», красиво только то, что красиво сейчас, и прекрасное - наивысшая жизненная ценность, выше гуманизма и личности. Но авторское представление об искусстве (суждения авторанарратора и Гарри) вступает в противоречие с представлениями художника Бэзила. Он уверен, что красота искусства зависит от того, сколько души вложил автор в свое творение. Авторская мысль развивается в несколько другом направлении: «иувства художника не отражаются на его творении. Искусство гораздо абстрактнее, чем мы думаем. Форма и краски говорлт нам лишь о форме и красках - и больще ни о чем. Мне часто приходит в голову, что искусство в гораздо большей степени скрывает художника, чем раскрывает его...» $[7$, с. 90]. В конце концов, в интеллектуальном соревновании со своим героем автор проигрывает, трагическая развязка романа, хотя и подводит к мысли, что вечна только красота и искусство, в то же время несет в себе и корректив, только то - искусство, в которое вложил душу его творец. А молодость и красота и даже талант без труда сами по себе не есть искусство. Это поздно 
понял гоголевский герой, об том догадался и Дориан Грей: «Эта красота его погубила, красота и вечная молодость, которую он себе вымолил! Если бы не они, его жизнь была бы чиста. Красота оказалась только маской, молодость - насмешкой. Что такое молодость в лучшем случае? Время незрелости, наивности, время поверхностных впечатлений и нездоровых помыслов. Зачем ему было носить ее нарлд? Да, молодость его погубила» [7, с. 166]. Вывод обоих писателей, при всех парадоксальных заявлениях их героев, напрашивается один - и жизнь, и искусство - это тексты, которые нужно вдумчиво прочитывать страница за страницей, приобретая опыт, развивая талант.

Таким образом, романтический и модернистский дискурс, представленный художественным приемом текста в тексте («живописного портрета» в литературном), подводит к заключению, что в искусстве, которое вечно, и Гоголь и Уайльд искали философского примирения с жизнью, совершенство гармонии и мира, разрешающего все противоречия. И если для Гоголя искусство - это результат духовного преображения человека, то для Уайльда - это эстетическое совершенство, стоящее над бесплодным скепсисом, нигилистическим отрицанием жизни и воплощающее торжество веры над неверием.

\section{1 Литература}

[1] Анненский И.Ф. Портрет // Анненский И.Ф. Избранное.-М., 1987.

[2] Гоголь Н.В. Собр.соч.: В 7-ми т. - М., 1977.

[3] Комков О.А. Категория личины и инфернальная эстетики повести Н.В. Гоголя // Вестник Московского университета.-Сер. 19, Вып. 3. - 2001. - С. 30-46.

[4] Манн Ю.В. Динамика русского романтизма.--М., 1995.

[5] Порфиръева Г.А. Проблема автора в романе О.Уайльда «Портрет»// Изв. АН СССР, Сер. лит и яз. - 1978. - Т. 37, №1.

[6] Стеквашов E. Проза Оскара Уайльда // Уайльд О. Портрет Дориана Грея.-Өлиста, 1986.

[7] Уайльд О. Портрет Дориана Грея. Тюремная исповедь. - К., 1993. 